\title{
Satisfaction of students toward using test retest method in reading and writing skills for Thai word
}

\author{
Nattharacha Chomphara ${ }^{1}$, Siriphon Srichantha ${ }^{2}$, Atikhun Sintanapanya ${ }^{3}$ \& Supachai Srichantha ${ }^{4}$ \\ ${ }^{1}$ Department of Thai Language, Faculty of Education, Loei Rajabhat University, Thailand \\ ${ }^{2}$ Independent scholar, Thailand \\ ${ }^{3}$ Senior Professional Level Teachers. Bangkhen (Wai Sali Anuson) School, Thailand \\ ${ }^{4}$ Kalasin Hospital, Thailand
}

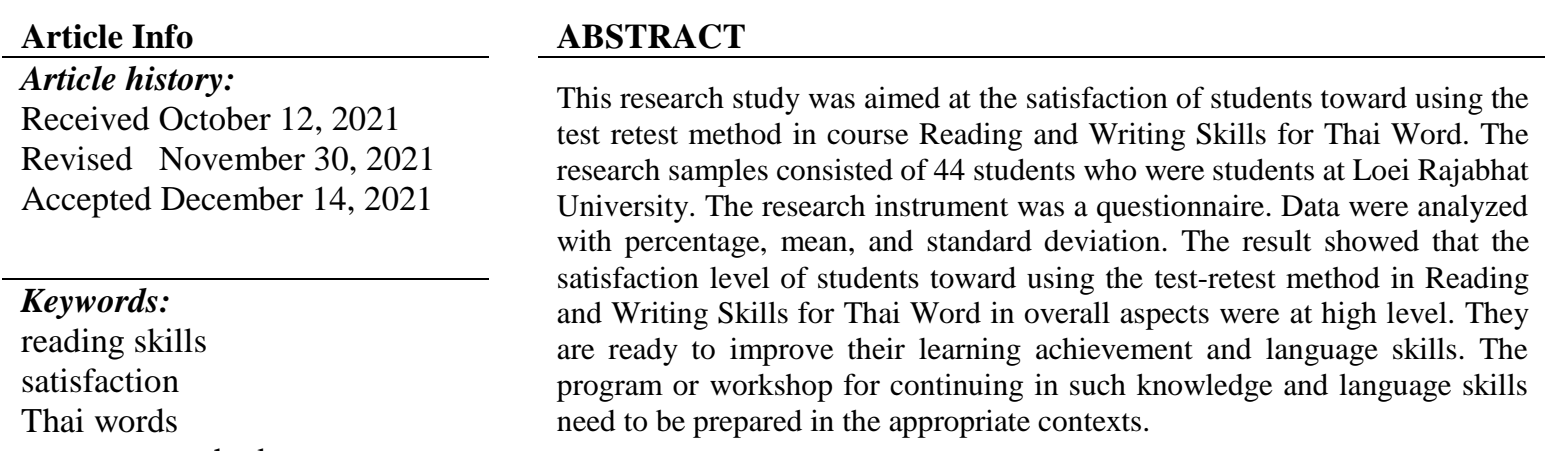

This is an open access article under the $\underline{C C B Y-S A}$ license.

test retest method

writing skills

\author{
Corresponding Author: \\ Nattharacha Chomphara \\ Deaperment of Thai Language \\ Faculty of Education \\ Loei Rajabhat University \\ Thailand \\ Email: nattarop2875@gmail.com
}

\section{INTRODUCTION}

Language has been designed by humans to communicate with each other. People must learn their own language to use it to communicate with maximum efficiency and effectiveness. This is achieved through the language learning process, in addition to learning through the process of imitation from people in society. Language is also learned through the education system., It is acknowledged that each country promotes and encourages its citizens to learn their own language as a compulsory subject from the beginning of their schooling (Poonsrichote, 2012).

At present, the reading and writing of Thai words is standardized based on the Thai dictionary which has been compiled by the Royal Institute. The government has notified wider general government agencies that from 1982 onwards, language learning should be of the same standard throughout the country, and that schools must adhere to the writing of words according to the Thai dictionary. This will be the case in teaching at all levels. Thus, the reading and writing of the words that have been distilled from the past will disappear. Words are a fundamental element of communication skill, be it listening, speaking, reading or writing, because they are the smallest level of meaning before they are combined into a sentence, a paragraph and, finally, a complete, detailed narrative. Therefore, the skill of mastering words is essential, a skill that neither teachers nor learners can avoid (Poonsrichote, 2012).

When considering the use of words by the Thai people today, there are several problems concerning reading and writing.. People may be influenced by others. One influential group is the mass media, based on its ability to reach people. There are many problems with the way the media use words, The unnecessary use of English words and sentences distort consonant pronunciation, for example, the incorrect pronunciation of the consonants ' $r$ ' and 'l', and diphthongs, etc. 
The Thai Language for Communication course focuses on enabling learners to use their Thai language skills to communicate with others correctly and appropriately. It is expected that teachers will find ways to develop the language skills of their learners to the maximum. If there is a problem with the use of words as a basic element of communication, it will lead to ineffective communication. There are many methods of teaching and learning that are student-centred. They all share one common idea, which is that learners must practice or apply what they are learning to acquire knowledge that will be durable. Application of the concept of the pratise od the used and the precise of the disused is required to create precise skills and more fluent (Guthrie, 1952; Mazur, 2006).

Learning by repetition, or practise by repetition, is a learning approach with an emphasis on learners that aims to develop their skills (Thorndike, 1920). This approach assumes that the learners want to respond to any stimuli, allowing them to practise repetition following the process set by their teachers. This will allow the learners to learn and develop durable skills. They can practice until it becomes a practical skill (Politano, 2000). As shown in language teaching guidelines that require learners to repeat, such as learning by the TPR (Total Physical Response) model, we want to achieve learning that is durable and accurate. The language must be practised repeatedly until it becomes a skill. Based on the foregoing, the researcher studied the satisfaction of Loei Rajabhat University Students when using the test-retest method in reading and writing Skills for Thai to improve and develop the teaching and learning to be more efficient and effective.

\section{METHOD}

\subsection{Population scope}

This research used a test group consisting of students enrolled in the Thai Language for Communication course. The group was taught by the researcher in semester 1 of the academic year 2020, LG 11 study groups, with a total of 44 students.

\subsection{Content scope}

The research focuses on the study satisfaction of Loie Rajabhat University Students when using the testretest method in reading and writing skills for Thai. A total of six aspects, which included content, instruction, teaching and learning activities, teaching evaluation, the learning environment, and the development of student characteristics.

\subsection{Procedure}

The researcher sent a questionnaire to the sample group of 44 students enrolled in the Thai language course. The sample group was willing to fill out the questionnaire and were prepared to submit it within the specified period.

\section{RESULT}

This research study was aimed at the Satisfaction of Loei Rajabhat University students toward using the test retest method in reading and writing skills for Thai word can be shown in Table 1 .

Table 1 Satisfaction level of students

\begin{tabular}{|c|c|c|c|}
\hline \multirow[t]{2}{*}{ Aspect } & \multicolumn{3}{|c|}{ Satisfaction level } \\
\hline & $\bar{x}$ & S.D & Meaning \\
\hline Course content & 4.01 & 0.68 & High \\
\hline 1. Consistent with the aim of the course & 4.02 & 0.55 & High \\
\hline 2. Modern course content that meets the needs & 4.01 & 0.59 & High \\
\hline 3. Important and interesting & 4.04 & 0.65 & High \\
\hline 4. Can be applied in life & 4.00 & 0.87 & High \\
\hline 5. Can be integrated with various subjects & 3.97 & 0.73 & High \\
\hline Teachers evaluation & 4.11 & 0.56 & High \\
\hline 1. Qualifications and experience suitable for the course taught & 4.24 & 0.70 & High \\
\hline 2. Ability to transfer knowledge & 3.95 & 0.64 & High \\
\hline 3. Specialized in the subjects taught & 4.36 & 0.59 & High \\
\hline 4. Enthusiasm for teaching & 4.29 & 0.57 & High \\
\hline 5. Behaves appropriately and sets a good example & 4.34 & 0.60 & High \\
\hline 6. Has professional ethics & 4.32 & 0.63 & High \\
\hline Teaching activity & 4.12 & 0.61 & High \\
\hline $\begin{array}{l}\text { 1. Uses teaching materials that are suitable for the course } \\
\text { being taught. }\end{array}$ & 3.99 & 0.66 & High \\
\hline $\begin{array}{l}\text { 2. Activities to encourage students to learn language for } \\
\text { practical/professional purposes }\end{array}$ & 3.95 & 0.64 & High \\
\hline $\begin{array}{l}\text { 3. Activities to promote students' ability to think critically and } \\
\text { creatively }\end{array}$ & 4.02 & 0.65 & High \\
\hline
\end{tabular}




\begin{tabular}{|c|c|c|c|}
\hline $\begin{array}{l}\text { 4. Activities to encourage students to learn to integrate } \\
\text { knowledge with life } \\
\text { 5. Opportunities for students to exchange knowledge with } \\
\text { teachers }\end{array}$ & $\begin{array}{l}3.96 \\
4.11 \\
\end{array}$ & $\begin{array}{l}0.65 \\
0.69\end{array}$ & High \\
\hline Teaching evaluation & 4.13 & 0.54 & High \\
\hline $\begin{array}{l}\text { 1. Measurement and evaluation are appropriate } \\
\text { 2. Clarity of evaluation criteria } \\
\text { 3. Has informed the learners of the pre-assessment criteria } \\
\text { 4. There are channels and procedures for reviewing } \\
\text { assessments } \\
\text { 5. Measurements and assessments are efficient and fair }\end{array}$ & $\begin{array}{l}4.07 \\
4.15 \\
4.25 \\
4.11 \\
4.10\end{array}$ & $\begin{array}{l}0.60 \\
0.66 \\
0.68 \\
0.66 \\
0.67\end{array}$ & $\begin{array}{l}\text { High } \\
\text { High } \\
\text { High } \\
\text { High } \\
\text { High }\end{array}$ \\
\hline $\begin{array}{c}\text { Factors of learning environment } \\
\end{array}$ & 4.11 & 0.56 & High \\
\hline $\begin{array}{l}\text { 1. Audio-visual equipment is appropriate } \\
\text { 2. Instructional media are appropriate } \\
\text { 3. The laboratory equipment is modern and suitable to } \\
\text { facilitate learning } \\
\text { 4. Classroom environment is appropriate } \\
\text { 5. There is a modern, appropriate and adequate information } \\
\text { system } \\
\text { 6. There are modern, appropriate and sufficient learning } \\
\text { resources (libraries, computers, etc.) }\end{array}$ & $\begin{array}{l}3.88 \\
3.83 \\
3.67 \\
3.72 \\
3.78 \\
3.74 \\
\end{array}$ & $\begin{array}{l}0.80 \\
0.84 \\
0.87 \\
0.80 \\
0.80 \\
0.78\end{array}$ & $\begin{array}{l}\text { High } \\
\text { High } \\
\text { High } \\
\text { High } \\
\text { High } \\
\text { High }\end{array}$ \\
\hline Development of student characteristics & 4.11 & 0.56 & High \\
\hline $\begin{array}{l}\text { 1. Moral and Ethics } \\
\text { 2. Knowledge } \\
\text { 3. Problem-solving skills } \\
\text { 4. Interpersonal relations and responsibilities } \\
\text { 5. Numerical analysis, communication, and information } \\
\text { technology } \\
\text { 6. Learning management }\end{array}$ & $\begin{array}{l}3.74 \\
4.01 \\
4.11 \\
4.12 \\
4.11 \\
4.11\end{array}$ & $\begin{array}{l}0.78 \\
0.68 \\
0.61 \\
0.61 \\
0.54 \\
0.56\end{array}$ & $\begin{array}{l}\text { High } \\
\text { High } \\
\text { High } \\
\text { High } \\
\text { High } \\
\text { High }\end{array}$ \\
\hline Overall & 4.09 & 0.56 & High \\
\hline
\end{tabular}

It was found that the satisfaction level overall, it is at a high level. When considering each aspect, it was found that all aspects were satisfied. Overall, it's at a very high level as well, can be sorted as follows: teaching evaluation, teaching activity, teachers evaluation, factors of learning environment, student characteristics of development, and course content.

\section{CONCLUSION}

The results of the study can be discussed as follows. It was found that the overall satisfaction levels of the Loei Rajabhat University Students LG 11 study group was at a high level. When considering each aspect separately, it was found that each aspect had a high level of satisfaction. The aspects considered were as follows: teaching evaluation, teaching activities, teacher evaluation, factors of learning environment, the development of student characteristics, and course content. It can be seen that the students' overall satisfaction in teaching and learning was at a high level. This is because the teaching took place at the higher education level. Most of the teaching aspects met the students' expectations. Based on this, we can say that the curriculum includes teaching and learning to suit the needs of students who have the main aim of applying their knowledge to their careers or in higher education.

\section{ACKNOWLEDGEMENT}

This research was sponsored by Faculty of Education, Loei Rajabhat University.

\section{REFERENCES}

Guthrie, E. R. (1952). The psychology of learning. New York: Harper \& Brothers.

Mazur, J. E. (2006). Learning and behavior. $6^{\text {th }}$ ed. N.J. : Pearson Education.

Politano, C. (2000). Brain-based learning with class. Canada : Portage \& Main Press.

Poonsrichote, P. (2012). Thai language used with the TV programs for youth on the channels 3, 5, 7, and 9.

Thesis, Chiang Mai Rajabhat University. (unpublished document)

Thorndike, E. L. (1920). Education : A first book. New York : Macmillan. 